\title{
Assessing equity of access in programs for young people
}

\author{
Adam Weiner \\ Population Council
}

Follow this and additional works at: https://knowledgecommons.popcouncil.org/departments_sbsr-pgy

Part of the Demography, Population, and Ecology Commons, Family, Life Course, and Society

Commons, Gender and Sexuality Commons, International Public Health Commons, and the Medicine and Health Commons

How does access to this work benefit you? Let us know!

\section{Recommended Citation}

Weiner, Adam. 2011. "Assessing equity of access in programs for young people," Promoting Healthy, Safe, and Productive Transitions to Adulthood Brief no. 28. New York: Population Council. 


\section{Assessing equity of access in programs for young people}

\section{Prepared by Adam Weiner}

Young people aged 10 to 19 make up almost 20 percent of the population in less developed regions (UNESA 2008). This vast, highly diverse population faces a variety of threats that could disrupt their healthy transition to adulthood, including early marriage and childbearing, school leaving, violence, exploitation, unemployment, and HIVIAIDS. Not all young people are equally vulnerable; factors such as age, sex, marital status, educational attainment, place of residence, and other demographic characteristics such as race, ethnicity, and language can increase vulnerability and may limit an individual's ability to access services and programs. Population Council research suggests that the majority of youth programs fail to reach the most vulnerable; most programs are only accessible to those with greater levels of social and human capital, such as an education or friendship networks (Weiner 2010).

\section{Coverage exercise: A tool to identify vulnerable subgroups} in need of attention

Recognizing the need for generating evidence to target vulnerable subgroups of young people effectively, the Population Council developed a tool to assess the equity of access to programs for adolescents. A coverage exercise (CE) is a relatively low-cost tool used to yield data on the demographic characteristics of the clients of a particular youth service, group of service providers, or organizations operating within a particular geographic area. It was designed to be a versatile mechanism for technical agencies and service providers to use in a variety of contexts. When used in conjunction with population-based data such as household surveys and censuses, it is a key component for identifying vulnerable subgroups of young people in need of attention.

The CE can be used in program-monitoring activities, situation analyses, or studies of youth and adolescence. The data help program staff to monitor progress in reaching target populations with specific program services. By implementing a CE early in the life of a program, planners

\section{A Coverage Exercise}

- is a low-cost tool for generating data on service provision to inform future program design and establish target populations;

- is a tool to monitor programs by measuring whether target populations are being reached with services; and

- yields valuable data for advocacy campaigns and policy analysis.

can analyze whether resources are being employed as originally intended and, if necessary, they can reorient strategies to ensure that they are on track for meeting programmatic goals and objectives.

The CE process begins with the collection of information on age, sex, schooling status, living arrangements, work status, marital status, and types of services received, among other variables. Data are collected by participating institutions and analyzed by technical consultants. The cross-tabulations, correlations, and descriptive statistics help to provide a picture of the subgroups of young people receiving services. The results enable program planners and managers, as well as UN agencies, government ministries, and other groups providing technical support to local programs, to monitor and review the services they provide in terms of whom they are reaching and with which types of services. Results of the diagnostic efforts are used to inform the design of follow-up activities and interventions to improve access to services for vulnerable young people. After this diagnostic phase, program staff reassess their priorities and may redirect their services to previously 
Table 1 Percent distribution of services delivered to beneficiaries by age group, sex, and ethnicity

(Tabulations by A. Weiner)

\begin{tabular}{|c|c|c|c|c|c|c|c|c|c|}
\hline \multirow[b]{2}{*}{ Ethnicity } & \multicolumn{4}{|c|}{ Females } & \multicolumn{4}{|c|}{ Males } & \multirow[b]{2}{*}{ Tota } \\
\hline & $10-14$ & $15-19$ & $20-24$ & Total & $10-14$ & $15-19$ & $20-24$ & Total & \\
\hline Ladino & 10.8 & 19.8 & 2.9 & 33.5 & 11.5 & 15.8 & 2.3 & 29.6 & 63.1 \\
\hline Mayan & 7.6 & 9.5 & 2.1 & 19.1 & 7.0 & 8.2 & 0.7 & 15.9 & 35.1 \\
\hline Other & 0.3 & 0.4 & 0.1 & 0.8 & 0.1 & 0.5 & 0.1 & 0.7 & 1.5 \\
\hline Total $(\mathrm{N}=12920)$ & 18.7 & 29.7 & 5.1 & 53.4 & 18.6 & 24.5 & 3.1 & 46.2 & 100 \\
\hline
\end{tabular}

underserved populations. In order to track this change over time, participating organizations may use the CE data collection instrument as an expanded version of a daily program register to follow participation and generate descriptive statistics to monitor progress on reaching their target population(s).

In all of the countries where CEs have been conducted, local organizations have chosen to participate with the intention of obtaining the evidence necessary to help them reach highly vulnerable youth in the areas where they operated. In Guatemala, nine organizations with multiple sites around the country participated in the $2007 \mathrm{CE}$ and collected data for a four-week period. These organizations offered a range of services to various subgroups of young people, but all shared the goal of reaching the poorest and most vulnerable in their communities.

Table 1 shows that only 19 percent of services recorded during the CE were used by adolescent Mayan girls, a group identified by Council research as being the most vulnerable in the country to poverty, early marriage, school leaving, and poor sexual and reproductive and over- all health. As a result, participating organizations devised strategies to reach these girls and other highly vulnerable young people who were not accessing the services being offered at the time of the $\mathrm{CE}$.

\section{Results of coverage exercises from seven countries}

To date, coverage exercises have been carried out in Burkina Faso, Ethiopia, Guatemala, Guinea Bissau, Liberia, Malawi, and Mauritania. In each country, local partners defined the scope of the CE and identified the participating organizations while working with the Population Council and other technical agencies to ensure the collection of highquality data. The results of the data analyses have been shared with a wide range of stakeholders both to inform them about common issues in youth service provision and to facilitate a discussion on youth-oriented policies and programs. Table 2 summarizes the CEs conducted to date indicating the number of participating organizations, number of beneficiaries, and a breakdown of the beneficiaries by age and sex.

Table 2 Profile of coverage exercises conducted to date

\begin{tabular}{|c|c|c|c|c|c|c|c|c|}
\hline \multirow[b]{2}{*}{ Country } & \multirow[b]{2}{*}{ Year } & \multirow[b]{2}{*}{$N_{p}$} & \multirow[b]{2}{*}{$N_{b}$} & \multicolumn{2}{|c|}{$\begin{array}{c}\text { Sex } \\
\text { distribution (\%) }\end{array}$} & \multicolumn{3}{|c|}{$\begin{array}{c}\text { Age } \\
\text { distribution (\%) }\end{array}$} \\
\hline & & & & Boys & Girls & $10-14$ & $15-19$ & $20+$ \\
\hline Burkina Faso & 2005 & 20 & 6,216 & 56 & 44 & 7 & 30 & 63 \\
\hline Ethiopia & 2003 & 13 & 10,866 & 58 & 42 & 22 & 45 & 33 \\
\hline Guatemala & 2007 & 9 & 12,920 & 47 & 53 & 37 & 54 & 9 \\
\hline Guinea Bissau & 2006 & 20 & 7,625 & 57 & 43 & 7 & 37 & 56 \\
\hline Liberia & 2008-09 & 39 & 12,043 & 36 & 64 & 23 & 39 & 34 \\
\hline Malawi & 2009 & 45 & 15,471 & 54 & 46 & 17 & 32 & 50 \\
\hline Mauritania & 2005 & 18 & 5,452 & 83 & 17 & 28 & 42 & 25 \\
\hline
\end{tabular}

Note: Data are not nationally representative. $N_{p}$ equals the number of programs assessed. $N_{b}$ equals the number of beneficiaries surveyed by these programs (some beneficiaries may have been surveyed more than once depending on the frequency of their participation or use of services). 


\section{Highlights of coverage exercises}

- Burkina Faso: The programs reached more boys than girls: At the national level, 69 percent of adolescent females and 53 percent of adolescent males are married (Macro International 2011), suggesting that a large proportion of adolescents are not being reached by the participating organizations. Only 7 percent of all individuals who met with peer educators were aged 10-14, 63 percent were aged $15-24$, and 30 percent were older than 25. Seventy-one percent of program beneficiaries were not married (Lardoux, Batebié, and Traoré 2006).

- Ethiopia: Ten out of 13 organizations were serving more males than females; 58 percent of the beneficiaries were male. All of the participating programs were based in urban areas although more than 80 percent of Ethiopian young people were estimated to live in rural areas. The majority of the organizations' contacts were with older individuals: only 22 percent of the beneficiaries were aged 10-14, and 14 percent were older than the maximum target age of 24 . Among urban adolescents in Ethiopia, only 66 percent of males and 52 percent of females are in school. Despite these overall low rates of school enrollment, a relatively high proportion of beneficiaries were in school at the time of the CE (78 percent), and in three of the 13 programs, more than 90 percent were in school (Mekbib et al. 2005).

- Guatemala: Fifty-three percent of recipients were females. Nineteen percent were Mayan females, and 16 percent were Mayan males. Eighty-five percent of young people were students at the time of the CE. More than 40 percent of all services were focused on SRH, and 18 percent were for programs focusing on personal development issues such as self-esteem and livelihoods. The remaining 42 percent of services were divided between sessions on civic education, human rights, gender, violence, or recreation (Tabulations of 2007 Guatemala CE data by author).

- Guinea Bissau: Approximately 57 percent of beneficiaries were males. Seven percent of program beneficiaries were aged 10-14, 37 percent were aged $15-19$, and 56 percent were older than age 20 (Lardoux, Cardoso, and Lopes 2006).

- Mauritania: A large majority (83 percent) of youth center clients were boys. Forty-two percent of visitors were 15-19-year-olds, whereas 28 percent were 10-14. Forty percent of boys and 24 percent of girls who visited the youth centers visited every day, whereas 27 percent of boys and 32 percent of girls visited two to three times a week (Lardoux, Ekeibed, and Bossou 2006).
- Liberia: Sixty-four percent of service recipients were females and 36 percent were males. Almost 80 percent of beneficiaries, regardless of where they lived, received services or participated in programs in urban areas, although 53 percent of the population live in rural areas (LISGIS 2009). The heaviest users of services were males and females aged 15-19. Three-fourths of all services were rendered to those older than 15 and approximately 15 percent were rendered to those older than 25 . The types of services received included general sexual and reproductive health (59\%) and livelihoods and life skills (4\%). The remaining 37 percent of services were divided between counseling, sports/recreation, education, food/agriculture, and other types not defined in the data. Almost 90 percent of beneficiaries were not married. In Liberia, 42 percent of adolescent females and 31 percent of adolescent males are married (Macro International 2011), suggesting an under-representation of married adolescents in the programs under study.

- Malawi: Almost one-fourth of all services were provided to females and males older than 24 , whereas almost one-third of all resources went to females and males aged 15-19. Thirty-eight percent of all services delivered were for health/SRH, 25 percent were for recreation, and only 8 percent were for asset-building programs. Fifty-four percent of recipients received services in urban areas. Sixty-three percent of beneficiaries were in school, whereas only 2 percent had never been to school (UNFPA/Malawi 2010). Nationally, 47 and 65 percent of females and males aged 15-19, respectively, are in school (Population Council 2009).

\section{Adapting the CE methodology to the local context}

The CE methodology is designed to be easily adapted to the needs of the institutions. Staff from the participating institutions attend a full-day training about the CE methodology and participate directly in the design of the data collection instrument. Service providers who have face-to-face interactions with program beneficiaries can use the tool to collect data during their daily interactions with clients. For example, a peer education program would use its peer educators to collect data directly from the youth. More recently, the CE instrument was revised to expand the daily program register that participants fill out themselves in order to avoid increasing the workload of the program staff. In these instances, staff were trained to administer the register and provide assistance to those young people who had difficulty answering the questions.

Given the nature of the process, it is possible to simultaneously carry out a CE of a particular program and the larger entity within which it is housed. For example, if a youth center offers a variety of activities or programs, a peer education CE can be included as part of a larger youth 
center analysis. One team can focus on the overall use of the center while peer educators collect data on outreach activities. Conducting a $\mathrm{CE}$ on both the youth center as a whole and its individual activities will yield a comprehensive understanding of the scope of services being offered and provide a representative view of the population being reached by an institution's programs.

\section{Available resources}

The Population Council's publication How to Conduct a Coverage Exercise: A Rapid Assessment Tool for Programs and Services is available to youth-oriented organizations to facilitate the development of programs that support the global effort to reach those who are most vulnerable to risk and to prepare them for the challenges they face in today's global culture. The English, Spanish, French, and Portuguese versions make the $C E$ a user-friendly tool that is accessible to a wide range of institutions.

\section{References and related publications}

Lardoux, Solène, Zio S. Batebié, and Siaka Traoré. 2006. "Exercice de couverture sur les activités des pairs éducateurs au Burkina Faso: Rapport Final." New York: Population Council and UNFPA.

Lardoux, Solène, Placido Cardoso, and Candida Lopes. 2006. "Exercice de couverture sur les activités des pairs éducateurs en Guinée Bissau: Rapport Final." New York: Population Council and UNFPA.

Lardoux, Solène, Mohamed Aly Ekeibed, and Yao Gaspard Bossou. 2006. "Exercice de couverture sur les activités et la fréquentation des centres de jeunes en Mauritanie: Rapport Final." New York: Population Council and UNFPA.
Liberia Institute of Statistics and Geo-Information Services (LISGIS). 2009. 2008 Population and Housing Census Final Results. Monrovia: LISGIS.

Lloyd, Cynthia B. (ed.). 2005. Growing Up Global: The Changing Transitions to Adulthood in Developing Countries. Washington, DC: National Academies Press.

Mekbib, T., A. Erulkar, and F. Belete. 2005. "Who are the targets of youth programs: Results of a capacity building exercise in Ethiopia," Ethiopian Journal of Health Development 19 (1): 60-62.

Macro International. 2011. MEASURE DHS STATcompiler. http://www. measuredhs.com. Accessed 8 March 2011.

Population Council. 2006. How to Conduct a Coverage Exercise: A Rapid Assessment Tool for Programs and Services. New York: Population Council.

Population Council. 2009. The Adolescent Experience In-Depth: Using Data to Identify and Reach the Most Vulnerable Young People (Malawi 2004). New York: Population Council.

Population Division of the Department of Economic and Social Affairs of the United Nations Secretariat (UNESA), World Population Prospects: The 2008 Revision, http://esa.un.org/unpp. Accessed 2 February 2011.

Weiner, Adam. 2010. "Geographic variations in inequities in access to services," Studies in Family Planning 41(2): 134-138.

\section{Donors}

Department for International Development (DFID), United Nations Population Fund (UNFPA), USAID, Futures Group, President's Emergency Plan for AIDS Relief

\section{Population Council}

The Population Council changes the way the world thinks about critical health and development issues. We seek to understand the causes and consequences of gender inequality and the disparities in opportunity that arise during adolescence. We provide the evidence for better on-theground programs and policies that ensure successful and productive transitions to adulthood in developing countries. www.popcouncil.org

() 2011 The Population Council, Inc. 